\title{
Interpretasi Genetik Pola Pita Isozim pada Cherax quadricarinatus Hasil Budidaya di Purwokerto dan Bogor
}

\section{Genetic Interpretation of Isozyme Banding Pattern of Cherax quadricarinatus Collected from Pound Culture in Purwokerto and Bogor}

\author{
Dian Bhagawati* dan Muh. Nadjmi Abulias \\ Fakultas Biologi Universitas Jenderal Soedirman Purwokerto 53122 \\ E-mail:dian_star05@yahoo.co.id *Penulisuntuk korespondensi
}

\begin{abstract}
A study on genetic interpretation of isozyme band patterns of $C$. quadricarinatus cultured in Purwokerto and Bogor showed the good visualization of aspartat transaminase, alkohol dehidrogenase, malat dehidrogenase, esterase and acid phosphatase. Twelve loci resulted low level of polymorphism $(\mathrm{P}=\mathbf{0 , 2 5})$ and also low valve of heterozygosity $(\mathrm{H}=0,09)$. It indicated that the genetic diversity of both populations was low.
\end{abstract}

Key words: Cherax quadricarinatus, genetic interpretation, isozyme

\begin{abstract}
Abstrak
Studi interpretasi genetik pola pita isozim pada $C$. quadricarinatus hasil budidaya di Purwokerto dan Bogor, menunjukkan visualisasi yang baik pada aspartat transaminase, alkohol dehidrogenase, malat dehidrogenase, esterase maupun fosfatase asam. Dua belas lokus menghasilkan tingkat polimorfisme yang rendah $(P=\mathbf{0 , 2 5})$ dan heterozigositas juga rata-rata rendah $(H=0,09)$. Hal ini mengindikasikan bahwa keragaman genetik kedua populasi rendah.
\end{abstract}

Kata kunci: Cherax quadricarinatus, interpretasi genetik, isozim

Diterima: 30 Oktober 2009, disetujui: 22 Maret 2010

\section{Pendahuluan}

Lobster air tawar yang dikenal di Indonesia, umumnya berasal dari Australia, utamanya jenis Cherax sp., yang dikembangkan sebagai ikan hias dan udang konsumsi (Susanto, 2008). Lobster juga menjadi salah satu komoditas perikanan tawar yang mulai dikembangkan untuk budidaya di Indonesia sejak tahun 2000 (Sukmajaya dan Suharja, 2003).

Salah satu jenis lobster air tawar adalah Cherax quadricarinatus yang dikenal pula sebagai red claw. Menurut Karplus et al., (2003), disebut red claw karena Cherax tersebut mempunyai warna merah pada capit bagian luarnya, khususnya pada yang jantan. Di samping itu, Cherax jenis ini mudah dibedakan dari Cherax jenis lain karena mempunyai empat buah lunas (carinae) pada bagian anterior karapaksnya, sehingga dinamakan quadricarinatus (quadri $=$ empat; carinatus $=$ carinae).
Studi genetika pada suatu populasi species organisme dimaksudkan untuk memberikan evaluasi mengenai variasi genetik populasi tersebut (Susanto dan Suryaningsih, 2006). Jika dibandingkan dengan variasi morfologi, data hasil studi variasi genetik relatif bebas dari pengaruh faktor lingkungan. Menurut Suryadi (2002) studi tentang variasi genetik merupakan aspek yang sangat penting dalam pelestarian dan juga pemanfaatan plasma nutfah.

Studi variasi genetik berdasarkan atas polimorfisme sejumlah lokus isozim dapat dengan cepat memberikan gambaran variasi genetik populasi yang dipelajari (Mansyah et al., 1999). Indriani et al., (2002) menyatakan bahwa semakin tinggi variasi genetik plasma nutfah, semakin besar peluang untuk memperoleh organisme dengan sifat yang diinginkan.

Keuntungan lainnya dalam penggunaan isozim adalah bahwa alel yang berbeda akan diwariskan secara kodominan sehingga individu homozigot dapat dibedakan dengan individu 
heterozigot berdasarkan penampilan pola pita yang dihasilkan. Selain itu, secara teknis peralatan dan bahan yang diperlukan relatif tidak terlalu mahal serta percobaan dapat dilakukan dengan mudah di laboratorium (Brar dalam Hardiati, 2002).

Dewasa ini, usaha budidaya lobster air tawar sudah banyak dilakukan oleh pembudidaya ikan, baik dalam skala besar maupun skala rumah tangga. Akan tetapi, dalam pengelolaannya, ternyata masih belum memperhatikan kualitas produknya. Umumnya, pembudidaya melakukan pemijahan secara masal berulang-ulang tanpa melakukan penggantian induk, sehingga ditakutkan akan menurunkan kualitas keturunannya, akibat terjadinya inbreeding.

Berkaitan dengan upaya mendapatkan informasi kualitas genetik lobster Cherax quadricarinatus, yang dibudidayakan pada skala rumah tangga oleh pembudidaya di Purwokerto dan Bogor, telah dilakukan penelitian untuk menginterpretasi visualisasi pola pita dari isozim aspartat transaminase (AAT), alkohol dehidrogenase (ADH), malat dehidrogenase (MDH), esterase (EST), acid phosphatase (ACP), dan peroksidase (PER). Hasil penelitian ini diharapkan dapat digunakan sebagai salah satu bahan pertimangan dalam pengelolaan pemijahan lobster Cherax quadricarinatus.

\section{Metode Penelitian}

Lobster Cherax quadricarinatus yang diteliti memiliki panjang tubuh rata-rata $12 \mathrm{~cm}$. Dari setiap lokasi diteliti sebanyak 10 ekor sampel dan terdiri atas 5 ekor lobster jantan dan 5 ekor lobster betina. Pengambilan sampel lobster dilakukan secara purposive random sampling. Penelitian dilakukan di Laboratorium Taksonomi Hewan Fakultas Biologi Unsoed dan di Laboratorium Biologi PSIH-IPB Bogor.

Analisis isozim dilakukan dengan teknik elektroforesis pada gel pati horisontal. Elektroforesis dilakukan pada tegangan 150 Volt selama 4 jam. Bahan kimia yang digunakan untuk elektroforesis meliputi buffer pengekstrak dengan komposisi (10 mM L-asam askorbat 0,07045 gr, $40 \mathrm{mM}$ L-sistein 0,1939 gr, Triton X-100 0,12 ml, PVP-40 0,25 gr) serta pelarut dan pengatur $\mathrm{pH}$ (akuades $40 \mathrm{ml}, \quad 0,1 \mathrm{M}$ $\mathrm{Na}_{2} \mathrm{HPO}_{4} \cdot 2 \mathrm{H}_{2} \mathrm{O} \mathrm{pH} 7$ ), buffer elektroda dengan komposisi $(50 \mathrm{mM}$ asam sitrat monohidrat $10,5507 \mathrm{gr}, \quad 150 \mathrm{mM}$ tris hidroksimetil aminometan $18,165 \mathrm{gr}$ serta pelarut dan pengatur $\mathrm{pH}$ (akuades $1000 \mathrm{ml} \mathrm{pH} \mathrm{6),} \mathrm{buffer} \mathrm{gel} \mathrm{dengan}$ komposisi (5 mM L-histidin monohidrat 1,048 gr, akuades $1000 \mathrm{ml}$ dan Tris $\mathrm{pH} \mathrm{6),} \mathrm{bromphenol}$ blue, pati untuk pembuatan gel dan pewarna enzim AAT dengan komposisi (L-asam keto glutamate $0.0292 \mathrm{gr}$, L-asam aspartat $1.07 \mathrm{gr}$, PVP-40 4 gr, EDTA Na2 Salt 0.4 gr, Na2HPO4. 2H2O 11.36 gr dan pelarut (akuades $800 \mathrm{ml}$ ), $\mathrm{ADH}$ dengan komposisi (NAD0.01 gr, Etanol $0.2 \mathrm{ml}$, NBT atau MTT $0.01 \mathrm{gr}$, PMS 0.002 gr) dan pelarut serta pengatur $\mathrm{pH}(5 \mathrm{mM}$ Tris HCL pH $8.050 \mathrm{ml}$ ), MDH dengan komposisi (NAD 0,01 gr, Asam malat 0,15 gr, NBT 0,01 gr, PMS 0,002 gr) dan pelarut serta pengatur $\mathrm{pH}(50 \mathrm{mM}$ tris $\mathrm{HCl} \mathrm{pH} 8,550 \mathrm{ml}$ ), EST dengan komposisi (1-naftil asetat 0,05 gr, 2-naftil asetat 0,05 gr, aseton $5 \mathrm{ml}$, Fast blue RR salt $0,1 \mathrm{gr}$ ) dan pelarut serta pengatur $\mathrm{pH}(100 \mathrm{mM}$ sodium fosfat $\mathrm{pH} 7$ $100 \mathrm{ml}$ ), ACP dengan komposisi (Na-a-napthyl acid phosphatase + aseton $50 \mathrm{gr}, \mathrm{MgCl} 250 \mathrm{gr}$, Fast Garnet GBG salt 50 gr) dan pelarut serta pengatur $\mathrm{pH}(5 \mathrm{mM}$ Natrium asetat $\mathrm{pH} 550 \mathrm{ml})$ dan PER dengan komposisi $\left(\mathrm{CaCl} 0,05\right.$ gr, $\mathrm{H}_{2} \mathrm{O}_{2}$ 3\% 0,5 ml, 3-amino 9-etil karbasol 0,05 gr, Aseton/N-dimetilformamid $5 \mathrm{ml}$ ) dan pelarut serta pengatur $\mathrm{pH}(50 \mathrm{mM}$ natrium asetat $\mathrm{pH} 5$ $100 \mathrm{ml}$ ).

Alat yang digunakan adalah electrophoresis stray, cetakan gel, pompa vakum, microwave dan lemari pendingin. Data yang diperoleh dari hasil elektroforesis ditransfer ke dalam zimogram untuk selanjutnya dilakukan perhitungan frekuensi alel dan heterozigositas menurut Hartl et al., (1994). Hasil perhitungan yang diperoleh dianalisis secara deskriptif untuk memberikan gambaran mengenai variasi biokimia genetik populasi.

\section{Hasil dan Pembahasan}

Hasil analisis terhadap enam isozim yang telah dilakukan terhadap lobster Cherax quadricarinatus, ternyata hanya lima pewarna yang dapat tervisualisasi dengan baik, yaitu AAT, ADH, MDH, EST dan ACP, sedangkan PER tidak dapat tervisualisasi. Kelima isozim 
tersebut tervisualisasi dalam 12 lokus, yang meliputi 3 lokus AAT, 1 lokus ADH, 2 lokus MDH, 4 lokus EST, dan 2 lokus ACP. Visualisasi pola pita kelima isozim tersebut tersaji pada Gambar 1-5.

Tidak tervisualisasinya isozim PER, kemungkinan karena penggunaan bufer tidak sesuai. Menurut Suryani et al., (2001), resolusi pita isozim dipengaruhi oleh kondisi bufer, khususnya komposisi kimia dan $\mathrm{pH}$ larutan. Bufer harus dapat menetralkan perubahan $\mathrm{pH}$ pada elektroda. Selain itu, tegangan yang rendah akan menghasilkan resolusi yang baik.

Hasil elektroforesis isozim AAT tervisualisasi pada Gambar 1 menunjukkan bahwa lobster air tawar asal Bogor, baik jantan maupun betina diduga diatur oleh tiga lokus (AAT-1, AAT-2 dan AAT-3) dengan satu pola pita. Pola pitanya berupa tiga pita tipis dengan jarak migrasi $1 \mathrm{~cm}, 2 \mathrm{~cm}$ dan mendekati $3 \mathrm{~cm}$, tervisualisasi pada sampel nomor 3 dan 4 . Lobster jantan asal Purwokerto, diduga diatur dua lokus dengan satu pola pita, berupa pita tipis dengan jarak migrasi $1 \mathrm{~cm}$ dan $2 \mathrm{~cm}$. Lobster betina, dikontrol oleh satu lokus dengan satu pola pita berupa satu pita tipis pada jarak $1 \mathrm{~cm}$ (Gambar 1).

Pada semua sampel arah migrasinya sama, yaitu menuju ke arah anoda serta memiliki struktur monomer. Hasil penelitian ini agak berbeda dengan beberapa penelitian yang telah dilakukan sebelumnya. Bhagawati dan Abulias (2007) memperoleh 2 lokus monomer pada ikan gurami. Sugama et al., (1996) menginformasikan bahwa pada Penaeus monodon terdapat 2 lokus AAT. Featherback fish mempunyai empat lokus AAT (Sodsuk dan Sodsuk, 2000), pada ikan Echinostomus gula, Eugerres plumieri serta Diapterus auratus, diketahui memiliki satu lokus AAT (Caruz dan Alcocer, 2003). Menurut Maltagliati (1998), isozim AAT pada Aphanius fasciatus tidak dapat divisualisasikan. Visualisasi pita isozim AAT pada lobster ini, juga tidak sesuai dengan pendapat Richardson et al., (1986), yang menyatakan bahwa pada umumnya AAT memiliki struktur subunit dimer.

Besarnya nilai frekuensi alel untuk tiaptiap lokus AAT pada Cherax quadricarinatus dapat dihitung sebagai berikut. Lokus AAT-1, AAT-2 dan AAT-3, masing-masing dikontrol oleh satu macam alel. Apabila alel tersebut diasumsikan sebagai alel A, maka frekuensi A, baik pada lokus AAT-1, AAT-2 maupun AAT-3 adalah 1,00. Oleh karena itu, berdasarkan atas pita-pita AAT yang tervisualisasikan tersebut, dapat dikatakan bahwa pada semua sampel lobster Cherax quadricarinatus yang dianalisis bersifat monomorfik.

Visualisasi isozim EST dari lobster jantan asal Purwokerto (Gambar 2) memberikan gambaran bahwa enzim tersebut diduga dikontrol oleh 4 lokus, sedangkan pada lobster betina asal Purwokerto dan lobster asal Bogor dikontrol oleh 3 lokus, yang mempunyai struktur subunit monomer.

Secara keseluruhan pola pita EST yang terbentuk sebanyak 2 macam. Pola pertama berupa 4 pita tipis dengan jarak $1 \mathrm{~cm}, 2 \mathrm{~cm}, 2,5$ $\mathrm{cm}$ dan $3 \mathrm{~cm}$, lobster jantan asal Purwokerto. Pola ke dua berupa 3 pita dengan jarak $2 \mathrm{~cm}, 2,5$ $\mathrm{cm}$ dan $3 \mathrm{~cm}$, tervisualisasi pada lobster betina asal Purwokerto serta lobster jantan dan betina asal Bogor.

Menurut Richardson et al., (1986) dan Nuryanto et al., (2002) pada umumnya ensim EST memiliki subunit dengan struktur monomer atau dimer. Abulias et al., (2005) mendapatkan informasi bahwa isozim EST pada gurami bule dan hitam diatur oleh dua lokus yang memiliki struktur subunit monomer. Sugama et al., (1996) menyatakan bahwa enzim EST pada Penaeus monodon diatur oleh dua lokus dengan struktur monomer. Menurut Bhagawati et al., (2005) isozim EST pada Penaeus monodon asal tambak di Brebes, Tegal dan Cilacap diatur oleh dua lokus dan memiliki struktur subunit monomer. Novianto et al., (2005) menginformasikan bahwa pada Achatina variegata diatur oleh tiga lokus yang masing-masing memiliki subunit monomer. Pada Pimelodus maculates dan Iheringichthys labrosus diatur oleh 4 lokus, sedangkan pada Pinirampus pinirampu diatur oleh dua lokus (Almeida dan Sodre, 1998). Hasil penelitian terhadap lobster ini, sama dengan beberapa hasil penelitian yang telah dilakukan sebelumnya, yaitu bahwa isozim EST memiliki struktur subunit monomer dan jumlah lokus yang mengatur pada masing-masing species bervariasi.

Nilai frekuensi alel dari masing-masing lokus pada EST dihitung atas dasar pita-pita yang diperoleh. Semua lokus yang tervisualisasi 
(EST-1, EST-2, EST-3 dan EST-4) dikontrol oleh satu macam alel (Gambar 2). Misalkan alel tersebut adalah alel A, maka besarnya nilai frekuensi alel A, pada masing-masing lokus adalah 1,00. Dengan demikian, dapat diartikan bahwa semua lokus EST yang tervisualisasi pada lobster tersebut bersifat monomorfik.

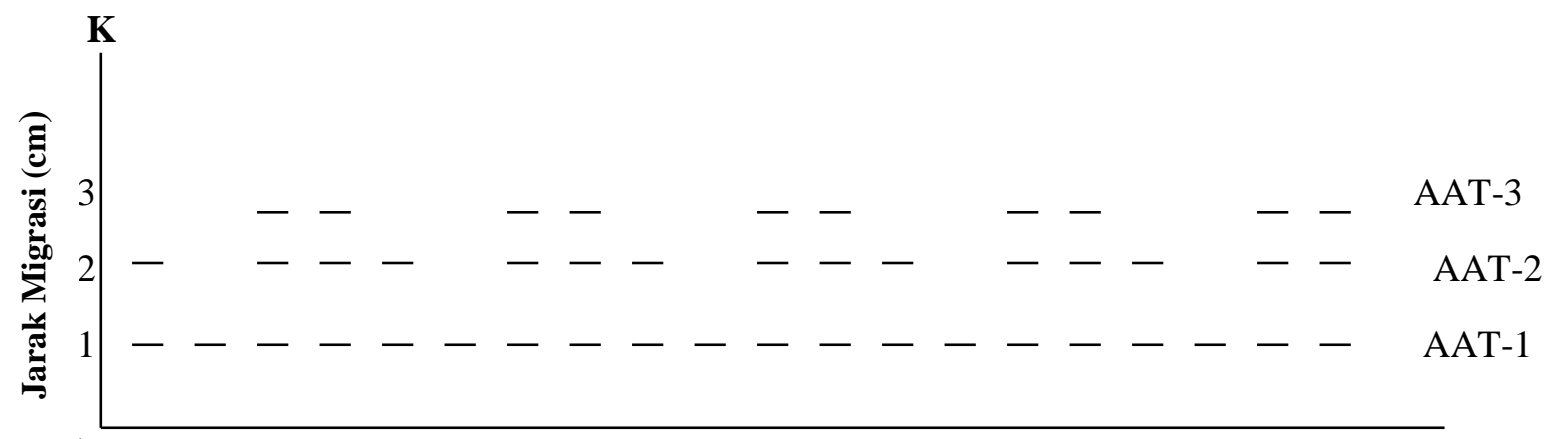
A.

2

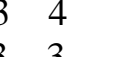

2

$\begin{array}{ll}3 & 3 \\ 3 & 3\end{array}$
B. 1120303

C. $\begin{array}{llllllllllllllllllll}2 & 1 & 3 & 3 & 2 & 3 & 3 & 3 & 2 & 1 & 3 & 3 & 2 & 1 & 3 & 3 & 2 & 1 & 3 & 3\end{array}$

Gambar 1. Zimogram AAT pada Cherax quadricarinatus hasil budidaya asal Purwokerto dan Bogor.
Keterangan: $\mathrm{A}=$ nomor sampel
$\mathrm{B}=$ pola pita
$\mathrm{C}=$ jumlah pita
1: C. quadricarinatus jantan asal Purwokerto
2: C. quadricarinatus betina asal Purwokerto
3: C. quadricarinatus jantan asal Bogor
4: C. quadricarinatus betina asal Bogor

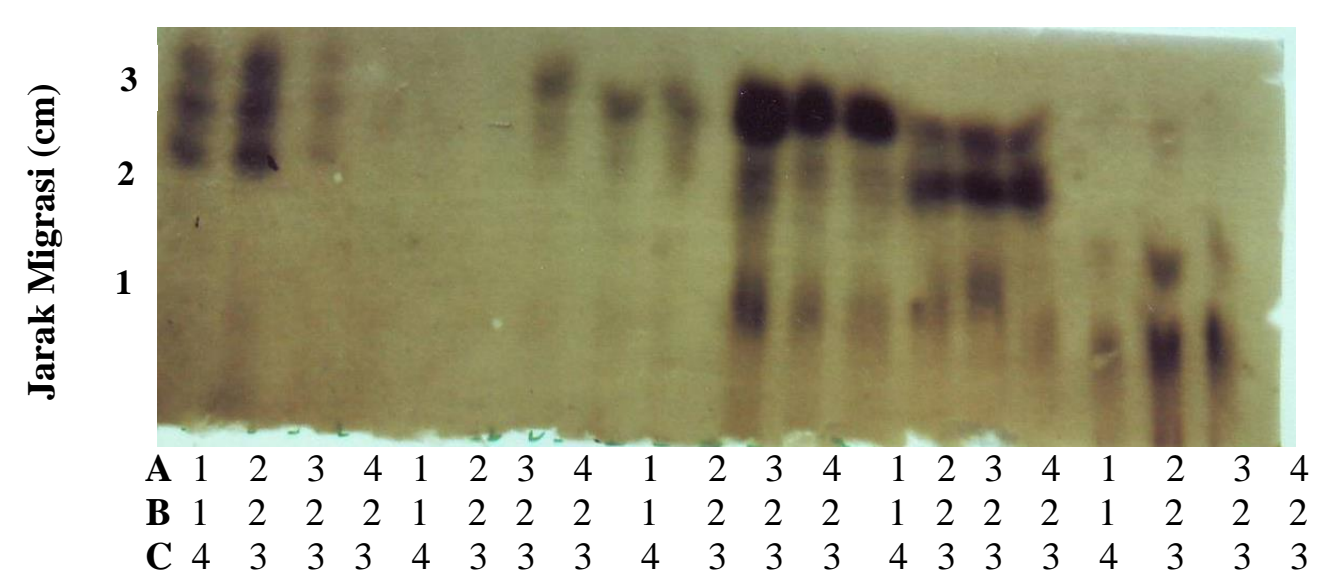

Gambar 2. Zimogram EST pada Cherax quadricarinatus hasil budidaya asal Purwokerto dan Bogor Keterangan : $\mathrm{A}=$ nomor sampel $\quad \mathrm{C}=$ jumlah pita

$$
\mathrm{B}=\text { pola pita } \quad \mathrm{K}=\text { posisi }
$$

1 : C. quadricarinatus jantan asal Purwokerto

2 : C. quadricarinatus betina asal Purwokerto

3 : C. quadricarinatus jantan asal Bogor

4 : C. quadricarinatus betina asal Bogor 
Hasil elektroforesis isozim ADH yang tervisualisasi pada Gambar 3 menunjukkan bahwa lobster Cherax quadricarinatus, diduga diatur oleh satu lokus, yang memiliki dua pola pita. Pola pertama dijumpai pada lobster jantan asal Purwokerto, yang berupa satu pita pada jarak migrasi $2 \mathrm{~cm}$. Adapun, lobster betina asal Purwokerto tidak memvisualisasikan isozim ADH. Pola kedua, terdiri atas dua pita dengan jarak migrasi $2 \mathrm{~cm}$ pada lobster asal Bogor.

Bhagawati et al., (2005), mendapatkan kenyataan bahwa enzim ADH yang divisualisasikan Penaeus monodon asal tambak di Brebes, Tegal, Cilacap dan Hatchery Cilacap diatur oleh dua lokus. Populasi asal Brebes, Cilacap dan Hatchery Cilacap menunjukkan adanya polimorfisme, sedangkan populasi Tegal tidak menunjukkan adanya polimorfisme. Pada Achatina variegata (Novianto et al., 2005), isozim $\mathrm{ADH}$ diatur oleh tiga lokus yang masingmasing memiliki struktur subunit monomer. Isozim ADH pada empat featherback fish dari familia Notopteridae, yaitu Nopterus notopterus, Chitala ornate, $C$. blanchi dan C. lopis, diketahui memiliki struktur subunit dimer dengan jumlah lokus satu buah (Sodsuk dan Sodsuk, 2000). Menilik hasil penelitian sebelumnya, maka dapat dikatakan bahwa hasil visualisasi isozim ADH pada lobster ini relatif sama dengan hasil beberapa penelitian terdahulu

Lokus isozim ADH pada Cherax quadricarinatus dikontrol oleh dua buah alel, misalkan alel tersebut adalah alel A dan alel a, maka atas dasar pola pita yang diperoleh dapat dihitung besarnya nilai frekuensi alel, yaitu $\mathrm{A}=$ 0,75 dan $\mathrm{a}=0,25$. Dengan demikian, lokus ADH bersifat polimorfik.

Zimogram MDH pada Cherax quadricarinatus yang berasal dari Purwokerto dan Bogor, memiliki 2 lokus yang mengatur 4 pola pitanya (Gambar 4). Sampel asal Purwokerto diatur oleh satu lokus, yang mengekspresikan pola pita pertama dan kedua, sedangkan sampel asal Bogor, diatur oleh dua lokus dengan dua pola pita (pola 3 dan 4). Pola pertama berupa satu pita dengan jarak migrasi 1 $\mathrm{cm}$ dan pola kedua berupa dua pita dengan jarak $1 \mathrm{~cm}$. Pola ketiga, berupa satu pita yang terdapat pada jarak migrasi lebih dari $1 \mathrm{~cm}$, sedangkan pola keempat, berupa satu pita yang terdapat pada jarak migrasi $1 \mathrm{~cm}$ dan $2 \mathrm{~cm}$.
Bhagawati et al., (2005) mendapatkan gambaran bahwa Penaeus monodon asal Brebes, Tegal dan Cilacap mampu memvisualisasi isozim MDH yang diatur 2 lokus, yaitu MDH-1 bersifat monomorfik dan $\mathrm{MDH}-2$ bersifat polimorfik. Sugama et al., (1996) dapat mendeteksi adanya dua lokus MDH pada Penaeus monodon dengan arah migrasi pita menuju ke anoda dan katoda. Novianto et al (2005), mendapatkan adanya dua lokus yang tervisualisasi pada Achatina variegata, yaitu MDH-1 bersifat polimorfik dan MDH-2 bersifat monomorfik. Menurut Abulias et al., (2005), isozim MDH pada ikan gurami bule dan hitam diatur oleh 1 lokus polimorfis. Oleh karena itu, dapat dikatakan bahwa hasil penelitian pada Cherax quadricarinatus ini, tidak berbeda dengan hasil penelitian yang telah dilaporkan sebelumnya.

Cherax quadricarinatus mampu memvisualisasikan dua lokus MDH dan berdasarkan pita-pitanya dapat dihitung besarnya nilai frekuensi alel. Lokus MDH-1, diasumsikan dikontrol oleh dua macam alel, jika alel tersebut adalah $\mathrm{A}$ dan a, maka frekuensi alel $\mathrm{A}$ adalah 0,875 dan alel a adalah 0,125. Lokus MDH-2, dikontrol oleh satu macam alel, bila alel tersebut adalah A, maka frekuensi alel A adalah 1,00. Dengan demikian, lokus $\mathrm{MDH}-1$ bersifat polimorfik dan lokus MDH-2 bersifat monomorfik.

Isozim ACP pada Cherax quadricarinatus asal Purwokerto dan Bogor yang tervisualisasi, diduga diatur oleh dua lokus dengan tiga pola pita. Pola pertama, berupa dua pita dengan jarak migrasi lebih dari $3 \mathrm{~cm}$, yang dijumpai pada lobster jantan asal Purwokerto. Pola kedua, tervisualisasi pada lobster betina asal Purwokerto dan betina asal Bogor yang berupa tiga pita, terdiri atas satu pita pada jarak migrasi mendekati $3 \mathrm{~cm}$ dan dua pita pada jarak migrasi lebih dari $3 \mathrm{~cm}$. Pola ketiga, yang dijumpai pada lobster jantan asal Bogor, berupa satu pita pada jarak migrasi $2,5 \mathrm{~cm}$ dan dua pita pada jarak lebih dari $3 \mathrm{~cm}$.

Isozim ACP pada Penaeus monodon asal tambak (Brebes, Tegal dan Cilacap) serta asal Hatchery Cilacap, menghasilkan pola pita yang sama dan diasumsikan bahwa izosim tersebut diatur oleh satu lokus yang memiliki struktur subunit monomer (Bhagawati et al., 2005). 
Menurut Nuryanto et al., (2003) pada sampel bekicot yang berasal dari kabupaten Wonosobo, Banjarnegara, Purbalingga dan Banyumas, isozim ACP tidak dapat tervisualisasikan dengan baik. Susanto et al., (2003) melaporkan bahwa isozim ACP dapat tervisualisasi dengan baik pada ikan bandeng. Hasil penelitian pada Cherax quadricarinatus ini terdapat perbedaan dengan hasil penelitian sebelumnya, terutama dengan Bhagawati et al., (2005).

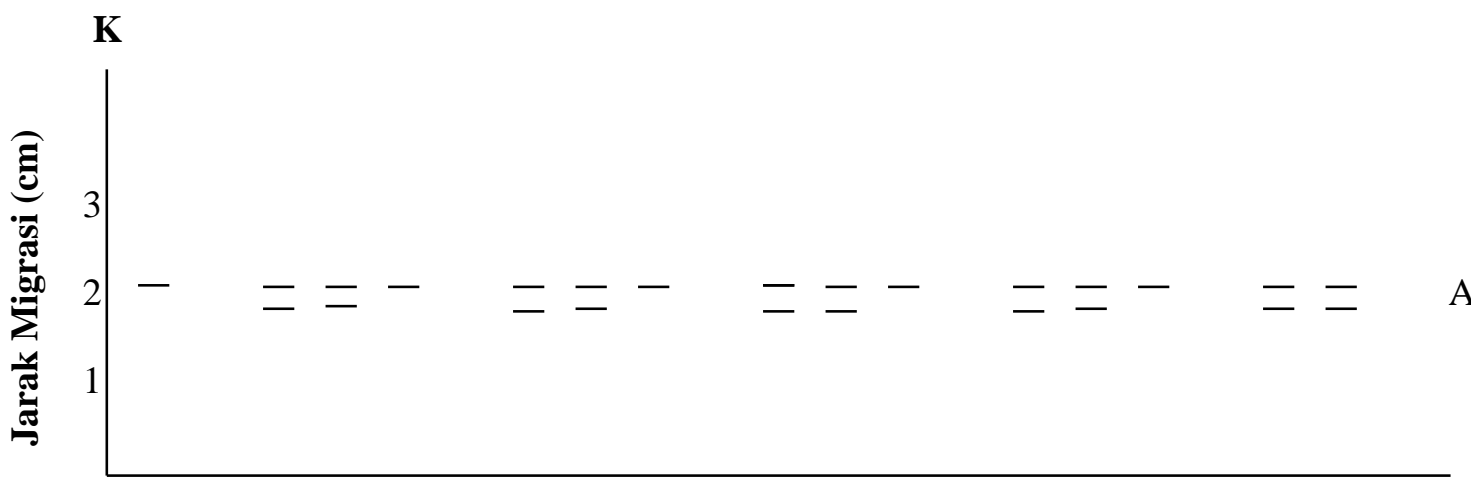

$\begin{array}{lllllllllllllllllllll}\text { A. } & 1 & 2 & 3 & 4 & 1 & 2 & 3 & 4 & 1 & 2 & 3 & 4 & 1 & 2 & 3 & 4 & 1 & 2 & 3 & 4 \\ \text { B. } & 1 & 0 & 2 & 2 & 1 & 0 & 2 & 2 & 1 & 0 & 2 & 2 & 1 & 0 & 2 & 2 & 1 & 0 & 2 & 2 \\ \text { C. } & 1 & 0 & 2 & 2 & 1 & 0 & 2 & 2 & 2 & 0 & 2 & 2 & 1 & 0 & 2 & 2 & 1 & 0 & 2 & 2\end{array}$

Gambar 3. Zimogram ADH pada Cherax quadricarinatus hasil budidaya asal Purwokerto dan Bogor

Keterangan : $\mathrm{A}=$ nomor sampel $\quad \mathrm{C}=$ jumlah pita

$\mathrm{B}=$ pola pita $\quad \mathrm{K}=$ posisi

$1:$ C. quadricarinatus jantan asal Purwokerto

2: C. quadricarinatus betina asal Purwokerto

$3:$ C. quadricarinatus jantan asal Bogor

4 : C. quadricarinatus betina asal Bogor

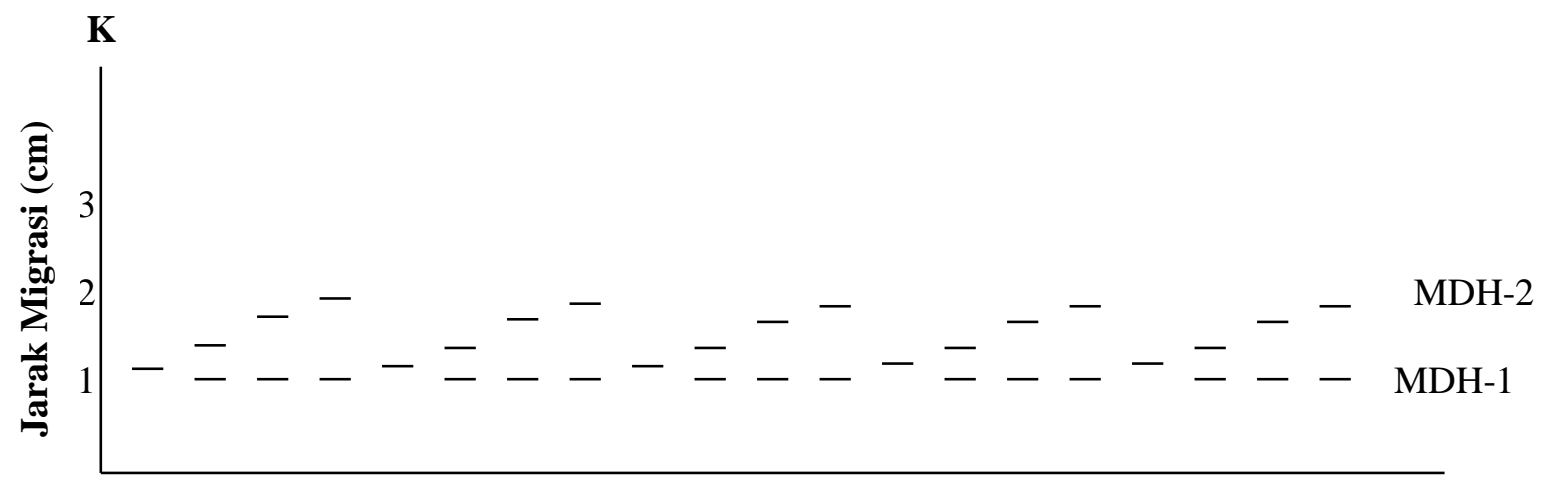

$\begin{array}{lllllllllllllllllllll}\text { A. } & 1 & 2 & 3 & 4 & 1 & 2 & 3 & 4 & 1 & 2 & 3 & 4 & 1 & 2 & 3 & 4 & 1 & 2 & 3 & 4 \\ \text { B. } & 1 & 2 & 3 & 4 & 1 & 2 & 3 & 4 & 1 & 2 & 3 & 4 & 1 & 2 & 3 & 4 & 1 & 2 & 3 & 4 \\ \text { C. } & 1 & 2 & 2 & 2 & 1 & 2 & 2 & 2 & 1 & 2 & 2 & 2 & 1 & 2 & 2 & 2 & 2 & 2 & 2 & 2\end{array}$

Gambar 4. Zimogram MDH pada Cherax quadricarinatus hasil budidaya asal Purwokerto dan Bogor

$$
\begin{gathered}
\text { Keterangan }: \mathrm{A}=\text { nomor sampel } \quad \mathrm{C}=\text { jumlah pita } \\
\mathrm{B}=\text { pola pita } \quad \mathrm{K}=\text { posisi } \\
1: \text { C. quadricarinatus jantan asal Purwokerto } \\
2: \text {. quadricarinatus betina asal Purwokerto } \\
3: \text { C. quadricarinatus jantan asal Bogor } \\
4: \text { C. quadricarinatus betina asal Bogor }
\end{gathered}
$$


Frekuensi alel untuk tiap-tiap lokus ACP diperhitungkan berdasarkan pita-pita yang terbentuk. Lokus ACP-1, dikontrol oleh satu macam alel, diasumsikan sebagai alel A, maka besarnya frekuensi alel A adalah 1,00. Lokus ACP-2, dikontrol oleh 2 alel, bila alel tersebut adalah A dan a, frekuensi alel A adalah 0,5 dan frekuensi alel a adalah 0,5. Dengan demikian, lokus ACP-1 bersifat monomorfik dan ACP-2 bersifat polimorfik.

Hasil perhitungan frekuensi alel dan polimorfisme lokus pada Cherax quadricarinatus yang terangkum pada Tabel 1, menunjukkan bahwa dari 12 lokus yang tervisualisasi, hanya terdapat 3 lokus yang bersifat polimorfik, yaitu $\mathrm{ADH}, \mathrm{MDH}-1$ dan ACP-2. Dengan demikian, derajat polimorfisme pada Cherax quadricarinatus hasil budidaya tersebut adalah 0,25 (25\%). Adapun nilai heterozigositas, yang terdapat pada lokus ADH, MDH-1 dan ACP-2, masing-masing yaitu 0,38, 0,23 dan 0,5 , sehingga nilai rata-rata heterozigositas dari kelima isozim yang diuji adalah $\mathrm{H}=0,09$.

Atas dasar nilai polimorfisme lokus dan heterozigositas yang diperoleh, dapat diartikan bahwa keanekeragaman genetik pada Cherax quadricarinatus hasil budidaya tersebut tergolong rendah. Kondisi tersebut terjadi

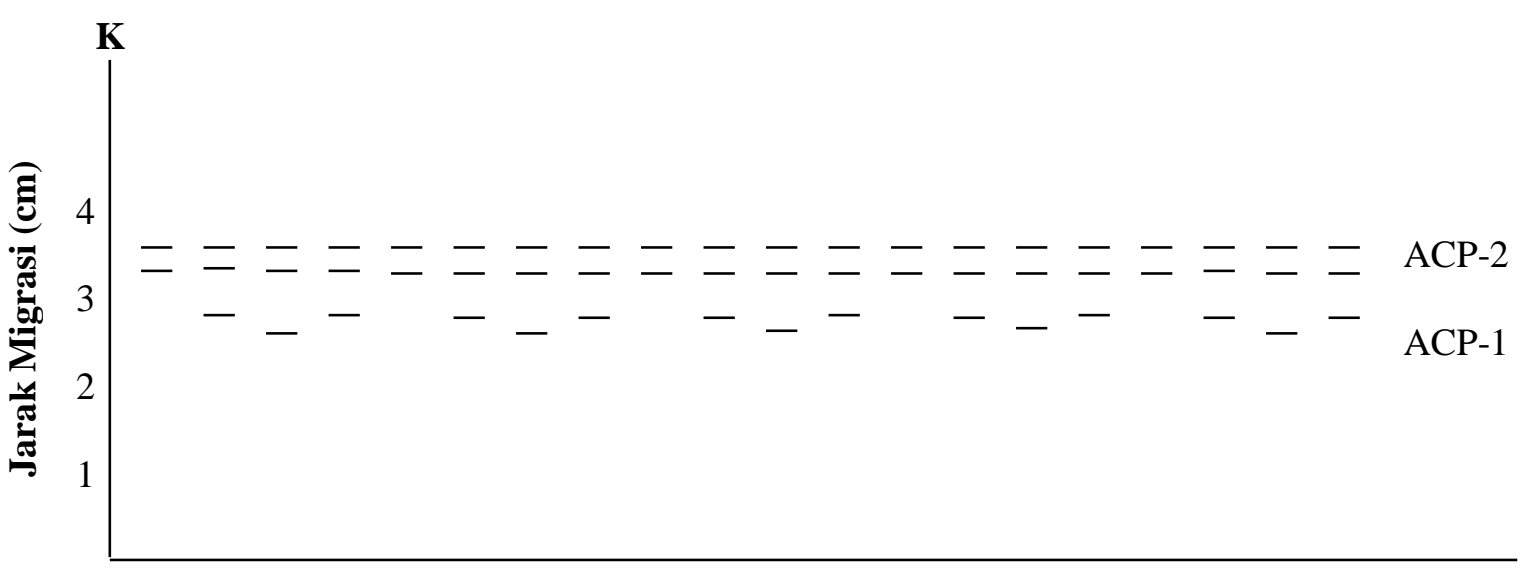

B. $\begin{array}{llllllllllllllllllll}1 & 2 & 3 & 2 & 1 & 2 & 3 & 2 & 1 & 2 & 3 & 2 & 1 & 2 & 3 & 2 & 1 & 2 & 3 & 2\end{array}$

C. $\begin{array}{llllllllllllllllllll}2 & 3 & 3 & 3 & 2 & 3 & 3 & 3 & 2 & 3 & 3 & 3 & 2 & 3 & 3 & 3 & 2 & 3 & 3 & 3\end{array}$

Gambar 5. Zimogram ACP pada Cherax quadricarinatus hasil budidaya asal Purwokerto dan Bogor

$$
\begin{gathered}
\text { Keterangan : } \mathrm{A}=\text { nomor sampel } \quad \mathrm{C}=\text { jumlah pita } \\
\mathrm{B}=\text { pola pita } \quad \mathrm{K}=\text { posisi } \\
1: \text { C. quadricarinatus jantan asal Purwokerto } \\
2: \text { C. quadricarinatus betina asal Purwokerto } \\
3: \text { C. quadricarinatus jantan asal Bogor } \\
4: \text { C. quadricarinatus betina asal Bogor }
\end{gathered}
$$


Tabel 1. Jumlah Lokus, Jumlah Genotip, Frekuensi Alel dan Polimorfisme lokus.

\begin{tabular}{|c|c|c|c|c|c|c|c|c|c|}
\hline \multirow{2}{*}{ No } & \multirow{2}{*}{ Isozim } & \multirow{2}{*}{ Lokus } & \multicolumn{3}{|c|}{ Jumlah Genotip } & \multirow{2}{*}{$\mathbf{N}$} & \multicolumn{2}{|c|}{ Frekuensi alel } & \multirow{2}{*}{ Polimorfisme } \\
\hline & & & $\mathbf{A A}$ & Aa & aa & & $\mathbf{A}$ & $\mathbf{a}$ & \\
\hline \multirow[t]{3}{*}{1.} & AAT & AAT-1 & 20 & 0 & 0 & 20 & 1,00 & 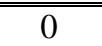 & $\overline{\mathrm{M}}$ \\
\hline & & AAT-2 & 15 & 0 & 0 & 15 & 1,00 & 0 & M \\
\hline & & AAT-3 & 10 & 0 & 0 & 10 & 1,00 & 0 & M \\
\hline \multirow[t]{4}{*}{2.} & EST & EST-1 & 5 & 0 & 0 & 5 & 1,00 & 0 & M \\
\hline & & EST-2 & 20 & 0 & 0 & 20 & 1,00 & 0 & M \\
\hline & & EST-3 & 20 & 0 & 0 & 20 & 1,00 & 0 & M \\
\hline & & EST-4 & 20 & 0 & 0 & 20 & 1,00 & 0 & M \\
\hline 3. & $\mathrm{ADH}$ & $\mathrm{ADH}$ & 5 & 10 & 0 & 15 & 0,75 & 0,25 & $\mathrm{P}$ \\
\hline \multirow[t]{2}{*}{4.} & $\mathrm{MDH}$ & MDH-1 & 15 & 5 & 0 & 20 & 0,875 & 0,125 & $\mathrm{P}$ \\
\hline & & MDH-2 & 10 & 0 & 0 & 10 & 1,00 & 0 & M \\
\hline \multirow[t]{2}{*}{5.} & $\mathrm{ACP}$ & ACP-1 & 15 & 0 & 0 & 15 & 1,00 & 0 & $\mathrm{M}$ \\
\hline & & ACP-2 & 0 & 20 & $\overline{c 0}$ & 20 & 0,5 & 0,5 & $\overline{\mathrm{P}}$ \\
\hline
\end{tabular}

Keterangan:

$\mathrm{A}=$ alel dengan migrasi cepat (fast allele)

$\mathrm{a}=$ alel dengan migrasi lambat (slow allele)

$\mathrm{N}=$ jumlah individu yang memvisualisasikan pita

\section{Simpulan dan Saran}

\section{Simpulan}

Dari hasil penelitian ini dapat disimpulkan bahwa: Isozim Aspartat aminotransferase, esterase, alkohol dehidrogenase, malat dehidrogenase dan acid phosphatase dapat divisualisasikan dengan baik pada Cherax quadricarinatus hasil budidaya asal Purwokerto dan Bogor, dideteksi ada 12 lokus dari lima isozim tersebut dianalisis dengan tingkat polimorfisme dan heterozigositas rendah.

\section{Saran}

Perlu dilakukan penelitian lebih lanjut untuk meningkatkan keragaman genetik lobster budidaya di Purwokerto dan Bogor dengan memberikan aliran gen baru dari sumber induk berbeda.

\section{Ucapan Terima Kasih}

Penulis mengucapkan terima kasih yang mendalam kepada DP2M DIKTI selaku penyandang dana dari penelitian ini, sesuai dengan Surat Perjanjian Kerja Penelitian Nomor:1582.08/H23.6/PL/2009, tanggal 6 April 2009. Ucapan terima kasih juga disampaikan kepada para penelaah atas masukan yang diberikan untuk perbaikan naskah ini.
$\mathrm{M}=$ monomorfik

$\mathrm{P}=$ polimorfik

\section{Daftar Pustaka}

Almeida, F.S. dan Sodre, L.M.K. 1998. Analysis of Genetic Variability in Three Species of Pimelodidae (Ostariophysi-Siluriformes). Genet. Mol. Biol., 21 (4): 1-5.

Bhagawati, D. dan Abulias, M.N. 2007. Karakter Meristik Bilateral dan Polimorfisme Isozim Sebagai Dasar Seleksi untuk Memproduksi Benih Gurami Unggul. Laporan Penelitian Fundamental. (Tidak dipublikasikan). Fakultas Biologi Unsoed Purwokerto.

Bhagawati, D., Abulias, M.N. dan Susanto, A.H. 2005. Analisis Kekerabatan Genetik Udang Windu dalam Upaya Mendukung Pemunculan Varietas Unggul Induk Penjenis. Laporan Penelitian Dasar. (Tidak dipublikasikan). Fakultas Biologi Unsoed Purwokerto.

Caruz, R.R. dan Alcocer, M.U. 2003. Phylogenetic Assessment of Eucinostomus gula, Eugerres plumieri and Diapterus auratus (Pisces: Gerreidae) Based on Allozyme and mtDNA Analyses. Caribbean J. of Science, 39 (1): 109-115.

Hadie, W. 2001. Konservasi: Strategi Etik dan Pendekatan Analisis Genetika Molekuler, Kasus pada Lele Lokal Clarias batrachus di Pulau Jawa. Makalah Falsafah Sains, Program Pasca sarjana IPB, Bogor.

Hardiati, S., Murdaningsih, A., Baihaki dan Rostini. 2002. Variasi Pola Pita dan Hubungan Kekerabatan Nanas Berdasarkan Analisis Isozim. Zuriat, 13 (2): $65-72$. 
Hartl, D.L., Freiferdel, D. dan Snyder, L.A. 1994. Basic Genetics. Jones \& Bartlett Publ. Inc., Boston.

Indriani, F.C., Lita, S., Sudjindro dan Arifm, N.S. 2002. Keragaman Genetik Plasma Nutfah Kenaf (Hibiscus cannabinus L.) dan Beberapa Species yang Sekerabat Berdasarkan Analisis Isozim. Biosain, 21.

Karplus, I., Amir, S., Isam, K. dan Assaf, B. 2003. The Soft Red Patch of The Australian Freshwater Crayfish (Cherax quadricarinatus (von Martens)): a Review and Prospects for Future Research. J. Zool. Lond., 259: 375-379.

Maltagliati, F. 1998. A Preliminary Investigation of Allozyme Genetic Variation and Population Geographical Structure in Aphanius fasciatus from Italian Brackish-Water Habitats. J. of Fish Biology, 52: 1130-1140.

Mansyah, E., Anwarudinsyah, M.J., Sadwiyanti, L. dan Susiloadi, A. 1999. Variabilitas Genetik Tanaman Manggis melalui Analisis Isozim dan Kaitannya dengan Variabilitas Fenotipik. Zuriat, 10 (1): 1-10.

Novianto, H.F., Susanto, A.H. dan Bhagawati, D. 2005. Interpretasi Genetik Pola Pita Isozim Pada Bekicot Achatina variegata Di Kabupaten Wonosobo, Jawa Tengah. J. Biologi, IX (2): 39-43.

Nuryanto, A., Sugiri, N., Syafei, D.S. dan Rahardjo, M.F. 2002. Pola Pita Beberapa Enzim Otot Ikan Nilem dari Dua Habitat Berbeda. Sain Akuatik, 5 (2): $38-44$.

Nuryanto, A., Soemarjanto dan Indarmawan. 2003. Analisis Kekerabatan Filogenetik Bekicot (Achatina sp) dari Kabupaten Wonosobo, Banjarnegara, Purbalingga dan Banyumas. Fakultas Biologi Unsoed, Purwokerto.
Richardson, B.J., Baverstock, P.R. dan Adams, M. 1986. Allozyme Electrophoresis; A Handbook for Animal Systematic and Population Studies. Academic Press, North Ryde.

Sugama, K., Haryanti dan Cholik, F. 1996. Biochemical Genetics of Tiger Shrimp Penaeus monodon: Description of Electrophoretic Detectabe Loci. IFR Journal, II (1): 19-28.

Sukmajaya, Y. dan Suharjo, I. 2003. Lobster Air Tawar Komoditas Perikanan Prospektif. Agromedia Pustaka. Jakarta.

Surjadi, H. 2002. Draft Dokumen IBSAP Bagian 3/8, Tinjauan: Keanekaragaman Hayati Sebagai Aset Produkstif Pembangunan Berkelanjutan. www.Polarhome.Com (Email: nasionala@polarhome).

Suryani, S.A.M., Sukoso dan Sugama. 2001. Hubungan Kekerabatan Tiga Species Ikan Kerapu Sunu (Plectropomus spp) Atas Dasar Variasi Genetik. Biosain, (1) : 3 .

Susanto, G.N. 2008. Pengamatan Masa Inkubasi Telur dan Perkembangan Awal Pada Larva Lobster Air Tawar, Red Claw (Cherax quadricarinatus). Prosiding Seminar Nasional Sains dan Teknologi-II. Universitas Lampung, 17-18 Nopember 2008.

Susanto, A.H. dan Suryaningsih, S. 2006. Variasi Biokimia Genetik Populasi Ikan Betutu (Oxyeleotris marmorata, BLKr.) di Waduk Penjalin Brebes. Biota, XI (3): 136-141.

Susanto, A.H., Amurwanto, A. dan Nuryanto, A. 2003. Studi keanekaragaman genetik ikan bandeng (Chanos chanos Forskal) di tambak perairan Pantai Cilacap dan Tegal untuk menunjang upaya konservasi hayati. Laporan Penelitian. (tidak dipublikasikan). Fakultas Biologi Unsoed, Purwokerto. 